\title{
Leaching of Primary Copper Sulfide Ore in Chloride-Ferrous Media
}

\author{
Karina E. Salinas ${ }^{1}$, Osvaldo Herreros ${ }^{2}$ and Cynthia M. Torres ${ }^{3, *}$ \\ 1 Departamento de Ingeniería Química y Procesos de Minerales, Universidad de Antofagasta, \\ Antofagasta 1240000, Chile; karinasalinasc@gmail.com \\ 2 Departamento Ingeniería de Minas, Universidad de Antofagasta, Antofagasta 1240000, Chile; \\ osvaldo.herreros@uantof.cl \\ 3 Departamento de Ingeniería en Metalurgia y Minas, Universidad Católica del Norte, \\ Antofagasta 1240000, Chile \\ * Correspondence: cynthia.torres@ucn.cl; Tel.: +56-552-651-022
}

Received: 28 June 2018; Accepted: 23 July 2018; Published: 25 July 2018

\begin{abstract}
Copper extraction from primary copper sulfide ore from a typical porphyry copper deposit from Antofagasta, Chile, was investigated after leaching with a chloride-ferrous media at two temperatures. The study focused on whether this chemical leaching system could be applied at an industrial scale. Leaching tests were conducted in columns loaded with approximately $50 \mathrm{~kg}$ of agglomerated ore; the ore was first cured for 14 days and then leached for 90 days. The highest copper extraction, $50.23 \%$, was achieved at $32.9^{\circ} \mathrm{C}$ with the addition of $0.6 \mathrm{~kg}$ of $\mathrm{H}_{2} \mathrm{SO}_{4}$ per ton of ore, $0.525 \mathrm{~kg}$ of $\mathrm{NaCl}$ per ton of ore, and $0.5 \mathrm{~kg}$ of $\mathrm{FeSO}_{4}$ per ton of ore. In respect to copper extraction, the most effective variables were temperature and the addition of $\mathrm{NaCl}$.
\end{abstract}

Keywords: leaching; primary sulfide copper; chalcopyrite; chloride

\section{Introduction}

Copper is considered the third most important metal for industry after iron and aluminum, with a yearly production of $10 \mathrm{Mt}$ [1]. In the north of Chile there are many mining industries that produce copper in cathodes from oxidized minerals with the traditional process of leaching, followed by solvent extraction (SX), and electrowinning (LIX-SX-EW). Due to the deepening of pits [2], depletion of oxidized ores and the presence of sulfide ore is noted, a situation that puts at risk the continuity of hydrometallurgical processes due to the lack of leachable mineral resources. Hence, different leaching techniques for copper sulfide ores, especially chalcopyrite, need to be investigated in the future.

Presently, the mining industry faces the challenge of extracting copper from low-grade copper ores. In 2002 the average copper ore grade was $1.13 \%$, while in 2011 it was $0.84 \%$ [3].

Many chalcopyrite leaching studies have been performed with leachants such as ferric sulfate [4-7], ferric chloride [7,8], sodium nitrate-sulfuric acid [9], hydrochloric acid [10], and sodium chloride-sulfuric acid [11], among others [10].

The slow copper from chalcopyrite dissolution has been attributed to the formation of a passivating layer on the mineral surface. This phenomenon has been widely studied, with no consensus regarding its cause or how to avoid its formation $[12,13]$. So far, three possible causes have been identified: (i) the formation of a layer of precipitated ferric iron that prevents contact between the chalcopyrite and the leaching solution [14,15], (ii) the formation of a layer of sulfur, which reduces the flow of electrons and the diffusion of the leaching agent to the mineral surface $[4,16,17]$, and/or (iii) the formation of an intermediate layer during the dissolution of chalcopyrite, such as a sulfide, disulfide, or polysulfide compounds, which have a slow kinetic dissolution $[12,18,19]$. Recent studies showed 
that passivation of chalcopyrite is dependent on redox potential (Eh) since high redox potentials (high concentration of ferric ions) promote passivation of chalcopyrite [5]. On the other hand, ferrous ions may increase the leaching kinetics significantly compared to ferric ions $[6,20,21]$. This is in contrast through to other leaching processes, such as the bacterial leaching of gold sulfide concentrates, where ferric iron promotes the dissolution of pyrite and arsenopyrite [22].

In addition, numerous studies showed that leaching of chalcopyrite in chloride media results in higher copper extractions than in sulfate media [16,23,24]. The main reasons are the formation of chloride complexes, which change the electrochemical behavior of chalcopyrite passivation and/or the higher porosity of the mineral surface $[8,16,25]$. For example, Dutrizac [7] associated the high percentages of copper extraction in a chloride medium to the lower activation energy of the medium, approximately $42 \mathrm{~kJ} / \mathrm{mol}$, compared with that in a sulfate medium $(75 \mathrm{~kJ} / \mathrm{mol})$.

Li et al. [26] and Kaplun et al. [27] demonstrated that the redox potential (Eh) significantly affects the leaching rate of chalcopyrite. To understand the effects of passivation during leaching processes, the passivation potential (Epp) has been used to determine the adequate potential to effectively leach the chalcopyrite. Chalcopyrite leached in a medium with sulfuric acid maintains its reactivity under $685 \mathrm{mV}$ (SHE) regardless of impurities, acidity, or temperature. Between 685 and $755 \mathrm{mV}$ (SHE), chalcopyrite may be in between the passive and active state, depending on the form at which that potential was reached. At $755 \mathrm{mV}$ (SHE) the leaching of chalcopyrite becomes slow due to the effect of passivation [28]. Sandström et al. [29] suggested that chalcopyrite leaching should be carried out in sulfuric acid medium at $620 \mathrm{mV}$ SHE, rather than at $800 \mathrm{mV}$ SHE.

The leaching of chalcopyrite at high potentials (high ferric concentration) has been questioned because some studies have shown that ferric ions inhibit the leaching of chalcopyrite [5] while ferrous ions increase its leaching kinetics [6]. Kametani and Aoki [21] established a critical reduction potential of $420 \mathrm{mV}$ versus $\mathrm{Ag} / \mathrm{AgCl}$ at which chalcopyrite dissolution reaches its maximum, demonstrating that there is an optimal concentration of ferrous ions that increase the leaching of chalcopyrite $[6,30]$. In addition, temperature is one of the most important parameters in the kinetics of chalcopyrite leaching [31], with the dissolution rate increasing at higher temperatures [23,32].

Nicol and coworkers [33-35] performed chalcopyrite leaching experiments in chloride solutions containing cupric ions and dissolved oxygen. As part of that overall program on the fundamental aspects of the heap leaching of copper sulfide minerals, Nicol [36] compared the anodic behavior of chalcopyrite at high potentials (transpassive region) in both sulfate and chloride solutions. Nicol et al. [37] studied the voltammetric characteristics of chalcopyrite under various conditions appropriate to low temperature leaching with acidic chloride solutions while Nicol and Basson [38] described the anodic behavior of covellite over a wide range of chloride concentrations at potentials relevant to its dissolution under ambient conditions similar to heap leaching. The other important aspect in column or heap leaching is the solution flowrate [39]. According to Ilankoon and Neethling [40], the way the solution spreads from drippers and the subsequent development of flow paths and any associated channeling needs to be properly investigated.

Actually, the current heap leaching process at mining companies involves a curing stage with the addition of $12 \mathrm{~kg}$ of sulfuric acid per ton of ore and a determined amount of Intermediate Pregnant Leach Solution (IPLS). The agglomerated ore is transported by conveyor belts to form 107 leach pads weighing a total of approximately 200,000 tons. Once the heap is formed, irrigation begins with a continuous leaching cycle of approximately 300 days. The modification proposed in this study includes the addition of reagents such as sodium chloride and ferrous sulfate in the agglomeration stage, together with the acid, and carrying out the leaching process at an average temperature of approximately $30^{\circ} \mathrm{C}$ to increase the percentage of copper extraction from primary sulfide ore.

The main objective of this work is to determine the effects of the modifications of the agglomeration-curing stages and the temperature on the copper extractions of the sulfidic ore. 


\section{Materials and Experimental Procedure}

\subsection{Materials}

\subsubsection{Ore Preparation and Sampling}

$500 \mathrm{~kg}$ of ore containing primary copper sulfide was obtained from a mine stockpile and crushed using a jaw crusher with a $152.4 \mathrm{~mm}$ aperture. Subsequently, sieve analysis was performed to obtain an ore sample with $\mathrm{P}_{(80)}$ of $11.5 \mathrm{~mm}$.

The ore retained in the meshes was classified by the cone and quartering technique to obtain the quantity needed to load the nine columns.

\subsubsection{Mineralogical Analysis}

The composition of sample of the ore was determined by mineralogical analysis using scanning electron microscopy and elemental analysis (SEM-EDX). To determine the composition of the gangue minerals and the ore, the sample particle size was reduced to $2 \mathrm{~mm}$ and was characterized by optical microscopy using point-counting method.

Most of the gangue is composed of potassium feldspar $(23.7 \%)$, plagioclase $(21.05 \%)$, biotite $(17.37 \%)$, quartz $(14.21 \%)$, sericite $(9.47 \%)$, and chlorite $(7.89 \%)$ (Table 1$)$, which are characteristics of porphyry copper deposits.

Table 1. Composition of the gangue minerals.

\begin{tabular}{ccc}
\hline Species & Chemical Formula & $\%$ wlw \\
\hline Kaolinite & & 1.05 \\
Smectite & $\mathrm{NaAlSi}_{3} \mathrm{O}_{8}$ & 1.05 \\
Albite & $\mathrm{K}\left(\mathrm{Mg}_{,} \mathrm{Fe}^{2+}\right)_{3}\left(\mathrm{AlSi}_{3} \mathrm{O}_{10}(\mathrm{OH}, \mathrm{F})_{2}\right.$ & 0.53 \\
Biotite & $\left(\mathrm{Fe}, \mathrm{Mg}_{5} \mathrm{Al}\right)\left(\mathrm{Si}_{1}, \mathrm{Al}_{4}\right)_{10} \mathrm{O}_{10}(\mathrm{OH})_{8}$ & 17.37 \\
Chlorite & $\mathrm{SiO}_{2}$ & 7.89 \\
Quartz & $\mathrm{Ca}_{2} \mathrm{Al}_{3} \mathrm{Si}_{3} \mathrm{O}_{12}(\mathrm{OH})$ & 14.21 \\
Epidote & $\mathrm{KAlSi}_{3} \mathrm{O}_{8}$ & 1.05 \\
Feld. & & 23.7 \\
Opaque minerals & & 2.63 \\
Plagioclase & $(\mathrm{Ca}, \mathrm{Na})(\mathrm{Al}, \mathrm{Si})_{3} \mathrm{O}_{8}$ & 21.05 \\
Sericite & $\mathrm{KAl}_{2}\left(\mathrm{Si}_{3} \mathrm{Al}\right) \mathrm{O}_{10}(\mathrm{OH}, \mathrm{F})_{2}$ & 9.47 \\
Total & & 100 \\
\hline
\end{tabular}

The mineralogical composition of the feed ore, Table 2, indicates that the ore consists of chalcopyrite $(0.55 \%)$, pyrite $(0.28 \%)$, covellite $(0.15 \%)$, and magnetite $(0.63 \%)$.

Table 2. The mineralogical composition of the feed ore determined by optical microscopy.

\begin{tabular}{cc}
\hline Feed Ore & $\% w / w$ \\
\hline Chalcocite & 0.04 \\
Covelite & 0.15 \\
Chalcopyrite & 0.55 \\
Bornite & 0.01 \\
Pyrite & 0.28 \\
Hematite & 0.02 \\
Magnetite & 0.63 \\
Ilmenite & 0.03 \\
Rutile & 0.01 \\
Gangue & 98.29 \\
Total & 100.00 \\
\hline
\end{tabular}


The mineralogical composition indicates $74.47 \%$ primary sulfides (i.e., chalcopyrite) and $25.52 \%$ secondary sulfides such as covellite and chalcocite.

\subsubsection{SEM-EDX Analysis of the Feed Ore}

Analysis of the feed ore sample was performed using a scanning electron microscope (JEOL model JSM 6360 LV, JEOL Ltd., Tokyo, Japan) equipped with a microscope-coupled X-ray dispersive energy analyzer (SEM-EDX).

The elemental composition of the feed ore indicates that it contains mostly oxygen, aluminum, and silica, so it can be concluded that it contains a large amount of aluminum silicates such as albite and biotite according to Table 1 .

Figures 1 and 2 show the SEM-EDX analysis of chalcopyrite (CPY) in the feed ore. In the sample it was possible to detect the presence of chalcopyrite, as shown in Figure 2.

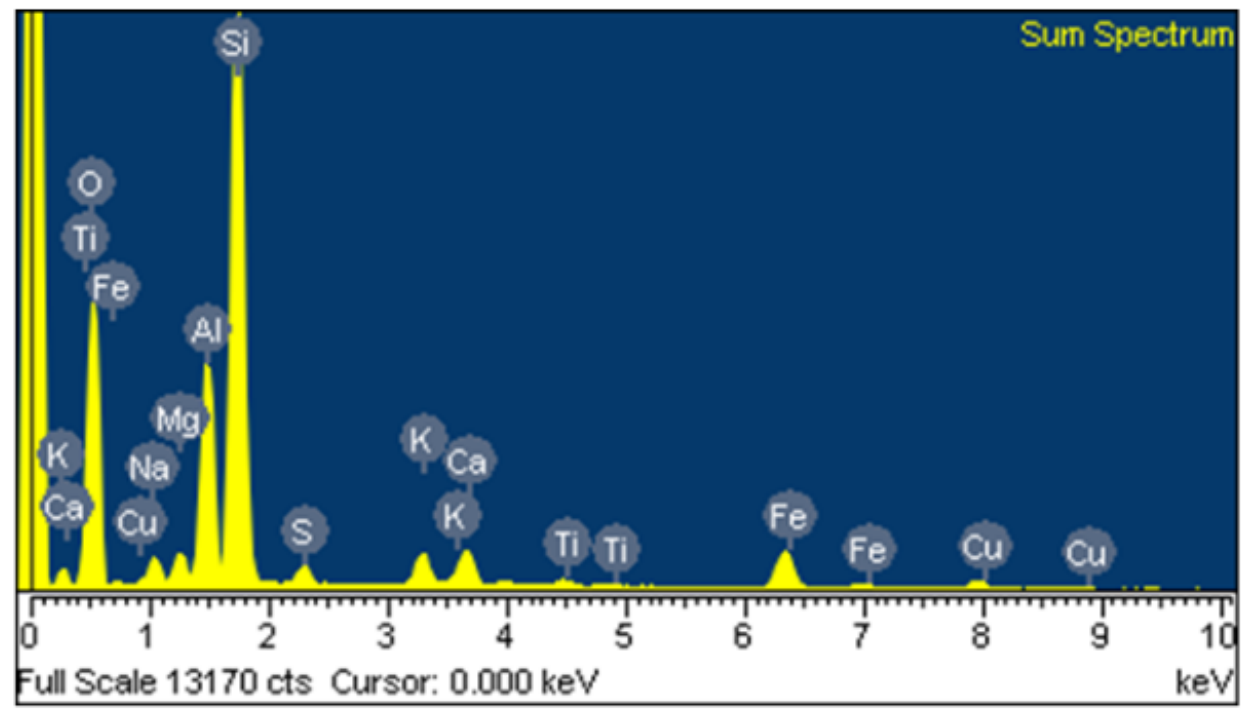

Figure 1. Elemental composition obtained by SEM-EDX analysis of Chalcopyrite (CPY) in the feed ore sample.

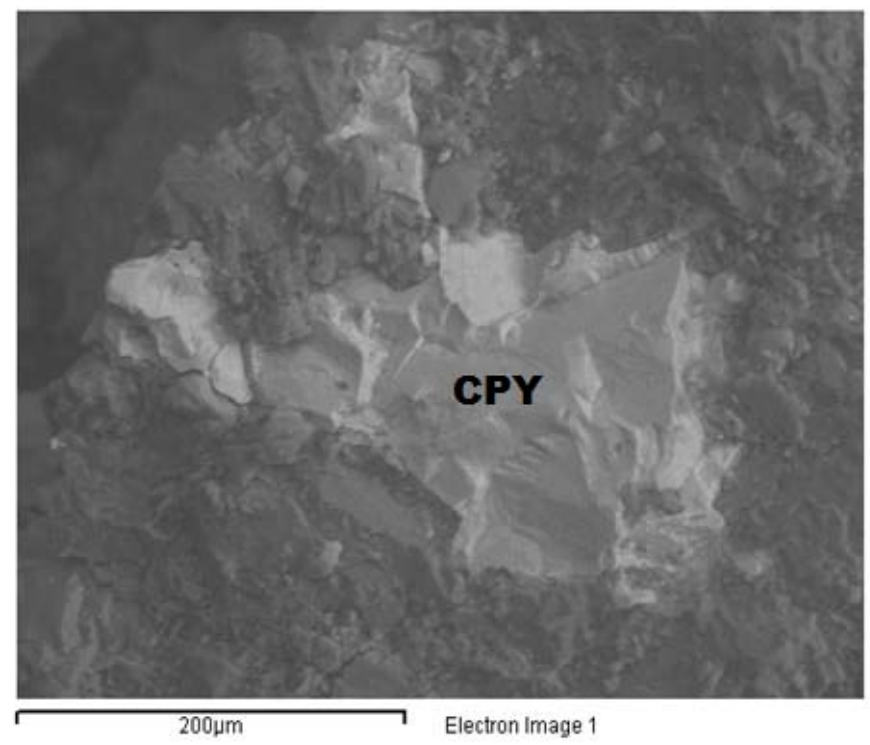

Figure 2. SEM image of chalcopyrite (CPY) in the feed ore sample showing chalcopyrite inclusion among gangue minerals. 


\subsubsection{Chemical Analysis of the Feed Ore}

A sample of ore was taken prior to loading each column to carry out chemical analysis by atomic absorption spectrometry (AA), using a Varian Model SpectrAA220 instrument (LabX Media Group, Midland, ON, Canada), and used to determine the ore grade through the sequential leaching method of copper. This analysis allows the estimation of the degree of solubility of copper-rich minerals in sulfuric acid and cyanide. The sulfuric acid leaching enables the dissolution of soluble copper oxides. The copper contained in the secondary sulfides and bornite was dissolved using a cyanide solution $(\mathrm{CNsCu})$. Residual copper $\left(\mathrm{Cu}_{\mathrm{r}}\right)$ corresponds to the copper present in the chalcopyrite.

The chemical analysis of the feed ore used in each column is shown in Table 3, from which it can be deduced that most of the copper is present as chalcopyrite.

Table 3. Chemical analysis of the feed ore used in each column *, showing the percentage of soluble copper $(\mathrm{Cu} \mathrm{S})$; Cyanidable copper $(\mathrm{CNsCu})$, and residual copper $\left(\mathrm{Cu}_{\mathrm{r}}\right)$.

\begin{tabular}{cccccccccc}
\hline Column Number & $\mathbf{1}$ & $\mathbf{2}$ & $\mathbf{3}$ & $\mathbf{4}$ & $\mathbf{5}$ & $\mathbf{6}$ & $\mathbf{7}$ & $\mathbf{8}$ & $\mathbf{9}$ \\
\hline Total Copper & 0.35 & 0.38 & 0.43 & 0.36 & 0.47 & 0.38 & 0.37 & 0.41 & 0.45 \\
Soluble Copper & 0.04 & 0.04 & 0.04 & 0.04 & 0.04 & 0.06 & 0.04 & 0.04 & 0.05 \\
Cyanidable Copper & 0.13 & 0.14 & 0.16 & 0.14 & 0.19 & 0.14 & 0.13 & 0.15 & 0.17 \\
Residual Copper & 0.18 & 0.20 & 0.23 & 0.18 & 0.24 & 0.18 & 0,20 & 0.22 & 0.23 \\
Total Iron & 4.88 & 4.95 & 4.90 & 4.82 & 4.97 & 4.94 & 4.64 & 4.87 & 4.67 \\
Soluble Iron & 0.45 & 0.37 & 0.38 & 0.39 & 0.40 & 0.39 & 0.32 & 0.46 & 0.45 \\
\hline
\end{tabular}

* See Table 4 for conditions of agglomeration in each column.

Table 4. Ore agglomeration conditions in columns prior to leaching.

\begin{tabular}{|c|c|c|c|}
\hline Column & $\mathrm{H}_{2} \mathrm{SO}_{4}(\mathrm{~kg} / 50 \mathrm{~kg}$ of Ore $)$ & $\mathrm{NaCl}(\mathrm{kg} / 50 \mathrm{~kg}$ of Ore) & $\mathrm{FeSO}_{4}(\mathrm{~kg} / 50 \mathrm{~kg}$ of Ore $)$ \\
\hline 1 & 0.6 & 0 & 0 \\
\hline 2 & 0.6 & 0 & 0.5 \\
\hline 3 & 0.6 & 0 & 1 \\
\hline 4 & 0.6 & 0.525 & 0 \\
\hline 5 & 0.6 & 0.525 & 0.5 \\
\hline 6 & 0.6 & 0.525 & 1 \\
\hline 7 & 0.6 & 0 & 0 \\
\hline 8 & 0.6 & 0.525 & 0 \\
\hline 9 & 0.6 & 0.525 & 0.5 \\
\hline
\end{tabular}

\subsection{Experimental Procedure}

\subsubsection{Agglomeration-Curing}

The agglomeration-curing stages were carried out in a drum, with a diameter of $30 \mathrm{~cm}$ and length of $40 \mathrm{~cm}$, during $5 \mathrm{~min}$ by adding sulfuric acid equivalent to $12 \mathrm{~kg}$ per ton of ore and the reagents (Table 4).

Once the ore was agglomerated, it was transferred to the columns and cured for 14 days under two different conditions: for columns $1-6$, the curing was temperature-controlled $\left(32.9^{\circ} \mathrm{C}\right)$ in a container equipped with an electric hot air generator, while columns $7-9$ were kept at $14.5^{\circ} \mathrm{C}$.

\subsubsection{Column Loading and Pumping System Installation}

PVC columns $1.5 \mathrm{~m}$ in height and $18 \mathrm{~cm}$ of diameter were used. Each column was loaded with $50 \mathrm{~kg}$ of ore $\left(\mathrm{P}_{(80)} 11.5 \mathrm{~mm}\right.$ ). An irrigation system with peristaltic pumps (Master Flex, 7557-14/1-100 RPM Model) and hoses of $13 \mathrm{~mm}$ diameter was installed to continuously irrigate the columns with IPLS or raffinate (Table 5). The temperature sensors were configured to measure the temperature every two hours. 
Table 5. Chemical composition of feed solutions.

\begin{tabular}{ccc}
\hline Element & Pregnant Leach Solution (PLS) & Raffinate \\
\hline Sulfuric Acid (g/L) & $8.21-8.64$ & $5.33-7.25$ \\
Total iron $(\mathrm{g} / \mathrm{L})$ & $4.14-4.58$ & $4.24-4.62$ \\
$\mathrm{pH}$ & 1.2 & $1.38-1.50$ \\
\hline
\end{tabular}

\subsubsection{Leaching}

Leaching was conducted in nine columns using IPLS (Intermediate Pregnant Leach Solution) at an irrigation rate of $8 \mathrm{~L} / \mathrm{m}^{2} \mathrm{~h}$ up to $1.6 \mathrm{~m}^{3} /$ ton, and later, with raffinate at an irrigation rate of $5 \mathrm{~L} / \mathrm{m}^{2} \mathrm{~h}$. In order to monitor the leaching process, daily samples of the feed solution and the discharge solution of each column were collected for analysis ( $\mathrm{Cu}$, total $\mathrm{Fe}$, and acidity). Table 5 shows the chemical composition of the IPLS and raffinate feed solutions. The concentrations of copper and iron were determined by atomic absorption spectrometry (AA) and the acidity was determined by titration with $\mathrm{NaOH}$.

The irrigation time for columns 1-6 was 90 days and for columns 7-9 it was 45 days. At the end of the experiment, the columns were irrigated with 3 liters of water, simulating a washing step for the remaining copper solution. The residual ore was then unloaded onto an HDPE folder and representative samples were taken by incremental division. The samples were dried at $90^{\circ} \mathrm{C}$ for $12 \mathrm{~h}$ and then crushed and pulverized. Sub-samples were subjected to sequential copper, total, and soluble iron analyses. The chemical analyses of the leachate and solid residues were used to calculate the amount of copper in extractions.

Leached residues from column 1 (agglomerated only with $\mathrm{H}_{2} \mathrm{SO}_{4}$ ) and column 5 (agglomerated with $\mathrm{H}_{2} \mathrm{SO}_{4}, \mathrm{FeSO}_{4}$, and $\mathrm{NaCl}$ ) were sampled for scanning electron microscopy analysis (SEM-EDX).

\section{Results and Discussion}

\subsection{Leaching Temperature, Oxidation-Reduction Potential and Acid Consumption}

An average temperature of $32.9^{\circ} \mathrm{C}$ was recorded in the heated columns (columns 1-6), and $14.5^{\circ} \mathrm{C}$ in columns 7-9. Acid consumption increased with temperature [6]. The maximum consumption calculated for the tests was approximately $36.5 \mathrm{~kg}$ acid $/$ ton ore for the heated columns at $32.9^{\circ} \mathrm{C}$ and $20 \mathrm{~kg}$ acid/ton ore for the columns operating at $14.5^{\circ} \mathrm{C}$.

The leaching solutions remained at a potential of about $600 \mathrm{mV}$ (vs. SHE) in all columns with no major variations in order to prevent the formation of a passivation layer that hinders the dissolution of copper.

\subsection{Copper Extraction}

\subsubsection{Chemical and SEM-EDX Analysis of the Residue}

The results of the chemical analyses of the residual ore in each column are presented in detail in Table 6.

Table 6. Chemical analysis of the residual ore in each column.

\begin{tabular}{cccccccccc}
\hline Column Number & $\mathbf{1}$ & $\mathbf{2}$ & $\mathbf{3}$ & $\mathbf{4}$ & $\mathbf{5}$ & $\mathbf{6}$ & $\mathbf{7}$ & $\mathbf{8}$ & $\mathbf{9}$ \\
\hline Total copper & 0.23 & 0.24 & 0.29 & 0.20 & 0.23 & 0.19 & 0.34 & 0.36 & 0.40 \\
Soluble copper & 0.02 & 0.02 & 0.02 & 0.02 & 0.02 & 0.02 & 0.02 & 0.02 & 0.03 \\
Cyanidable copper & 0.06 & 0.07 & 0.08 & 0.05 & 0.04 & 0.04 & 0.12 & 0.13 & 0.16 \\
Residual copper & 0.15 & 0.16 & 0.19 & 0.14 & 0.17 & 0.13 & 0.20 & 0.21 & 0.21 \\
Total iron & 4.6 & 4.77 & 4.65 & 4.79 & 4.91 & 4.97 & 4.74 & 4.71 & 4.68 \\
\hline
\end{tabular}


The analysis of the residues in column 1 (ore agglomerated with sulfuric acid and leached at $32.9^{\circ} \mathrm{C}$ ) using SEM shows that the ore still contains chalcopyrite but with a less crystalline appearance as a result of leaching (Figure 3 and Table 7).

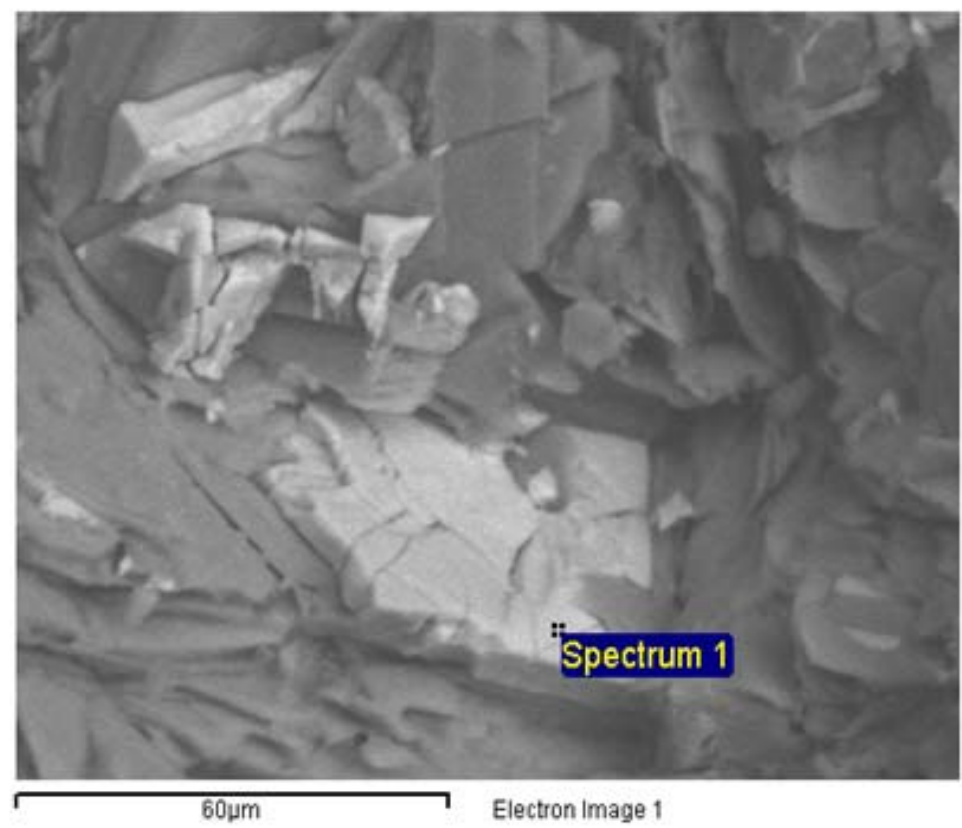

Figure 3. Chalcopyrite in the leach residues of column 1.

Table 7. Chalcopyrite in the leached residues of column 1.

\begin{tabular}{cc}
\hline Element & Weight (\%) \\
\hline $\mathrm{S}$ & 66.58 \\
$\mathrm{Fe}$ & 19.09 \\
$\mathrm{Cu}$ & 14.33 \\
Total & 100 \\
\hline
\end{tabular}

The results in Table 7 indicate that the grains comprise partly reacted chalcopyrite, coated with a layer of sulfur. This is deduced from the presence of $66.58 \%$ sulfur, compared with the theoretical sulfur content in chalcopyrite of $34.8 \%$.

\subsubsection{Extraction of Copper}

Table 8 shows the percentage of total copper extraction, with the respective percentages of extraction from copper oxides and sulfides in each column based on the analysis of feed ore and residue of each column.

Table 8. Percentage of copper extraction from oxides and sulfides.

\begin{tabular}{cccccccccc}
\hline Column Number & $\mathbf{1}$ & $\mathbf{2}$ & $\mathbf{3}$ & $\mathbf{4}$ & $\mathbf{5}$ & $\mathbf{6}$ & $\mathbf{7}$ & $\mathbf{8}$ & $\mathbf{9}$ \\
\hline Extraction of total copper (\%) & 35.4 & 35.8 & 33.7 & 44.2 & 51.9 & 50.3 & 9.9 & 13.0 & 12.4 \\
Extraction of oxide copper (\%) & 57.5 & 57.5 & 62.5 & 62.5 & 60.0 & 71.7 & 45.0 & 50.0 & 50.0 \\
Extraction of sulfide copper (\%) & 32.6 & 33.2 & 30.8 & 41.9 & 51.2 & 46.3 & 5.7 & 9.1 & 7.7 \\
\hline
\end{tabular}

From Table 8, it is noted that the use of $\mathrm{NaCl}$ and $\mathrm{FeSO}_{4}$ during leaching carried out at $32.9^{\circ} \mathrm{C}$ resulted in an increase in the extraction of copper from sulfides and a slight increase in the respective extraction from oxides. However, the use of these reagents during leaching at $14.5^{\circ} \mathrm{C}$ results in the low extraction of copper from sulfides, thus indicating the effect of temperature on leaching. 
In Figure 4, the results of copper extraction during the stages of agglomeration and curing (from 0 to 14 days), and leaching (from day 14 onwards) are compared. The results indicate that the extraction of copper during the leaching stage at $14.5^{\circ} \mathrm{C}$ is not significant, and the curves tend to be asymptotic. However, when the temperature was increased to $32.9^{\circ} \mathrm{C}$, copper extractions during the leaching stage improved.

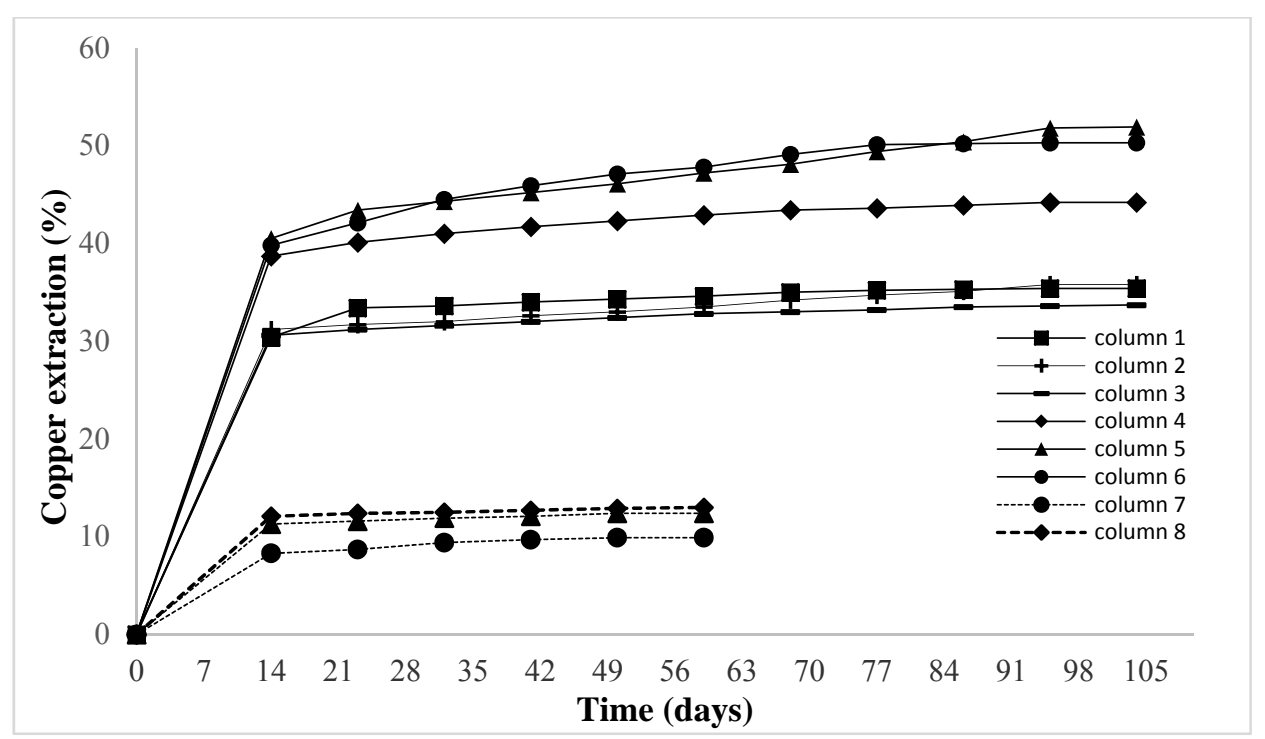

Figure 4. Extractions of copper during agglomeration-curing and leaching stages. Black (-) and dotted (-) lines correspond to the experiments performed at 32.9 and $14.5^{\circ} \mathrm{C}$ in columns, respectively. Discontinuous vertical lines show the division between the agglomeration-curing and leaching stages.

\subsubsection{Effect of Temperature, and Sulfuric Acid Used during Agglomeration}

Table 9 shows the extraction of copper for columns 1 and 7 as calculated by chemical analysis of the feed ore and residue. Columns 1 and 7 were leached at $32.9^{\circ} \mathrm{C}$ and $14.5^{\circ} \mathrm{C}$, respectively.

Table 9. Copper extractions in column $1\left(32.9^{\circ} \mathrm{C}, 0.6 \mathrm{~kg} \mathrm{H}_{2} \mathrm{SO}_{4} / 50 \mathrm{~kg}\right.$ of ore, $0 \mathrm{NaCl}, 0 \mathrm{FeSO}$ ) and column $7\left(14.5^{\circ} \mathrm{C}, 0.6 \mathrm{~kg} \mathrm{H}_{2} \mathrm{SO}_{4} / 50 \mathrm{~kg}\right.$ of ore, $\left.0 \mathrm{NaCl}, 0 \mathrm{FeSO}_{4}\right)$.

\begin{tabular}{ccccccc}
\hline & \multicolumn{3}{c}{ Column 1 } & \multicolumn{3}{c}{ Column 7 } \\
\hline & Initial & Residue & \% Ext & Initial & Residue & \% Ext \\
\hline Total copper & 0.35 & 0.23 & 35.4 & 0.37 & 0.34 & 9.9 \\
Soluble copper & 0.04 & 0.02 & 50.0 & 0.04 & 0.02 & 50.0 \\
Cyanidable copper & 0.13 & 0.06 & 53.8 & 0.13 & 0.12 & 7.7 \\
Copper in residue & 0.18 & 0.15 & 16.7 & 0.20 & 0.20 & 0.0 \\
Total iron & 4.88 & 4.60 & & 4.64 & 4.74 & \\
\hline
\end{tabular}

The effect of temperature is significant in the leaching of cyanidable copper, which corresponds to the dissolution of chalcocite and covellite present in the ore. On the other hand, the copper remaining in the residues, which corresponds to the chalcopyrite, shows that no dissolution takes place in column 7 .

\subsubsection{Effect of Temperature and Sulfuric Acid/Sodium Chloride Used during Agglomeration}

Table 10 shows the comparison of the columns 4 and 8, which were agglomerated with both $\mathrm{H}_{2} \mathrm{SO}_{4}$ and $\mathrm{NaCl}$. Column 4 was leached at $32.9^{\circ} \mathrm{C}$, column 8 at $14.5^{\circ} \mathrm{C}$.

Column 4 shows $64.3 \%$ extraction from chalcocite-covellite, while column 8 shows only $13.3 \%$ extraction. With regard to the leaching of chalcopyrite (based on the copper present in the residue) 
column 4 shows an extraction of $22.2 \%$, while column 8 only $4.5 \%$. These results are according with those reported in the literature (Al-Harahsheh et al. [20], Kimball et al. [28], Lu et al. [29]).

Table 10. Copper extractions in column $4\left(32.9^{\circ} \mathrm{C}, 0.6 \mathrm{~kg} \mathrm{H}_{2} \mathrm{SO}_{4} / 50 \mathrm{~kg}\right.$ of ore, $0.525 \mathrm{~kg} \mathrm{NaCl} / 50 \mathrm{~kg}$ of ore, $\left.0 \mathrm{FeSO}_{4}\right)$ and column $8\left(14.5^{\circ} \mathrm{C}, 0.6 \mathrm{~kg} \mathrm{H}_{2} \mathrm{SO}_{4} / 50 \mathrm{~kg}\right.$ of ore, $0.525 \mathrm{~kg} \mathrm{NaCl} / 50 \mathrm{~kg}$ of ore, $\left.0 \mathrm{FeSO}_{4}\right)$.

\begin{tabular}{ccccccc}
\hline & \multicolumn{3}{c}{ Column 4 } & & \multicolumn{2}{c}{ Column 8 } \\
\hline & Initial & Residue & \% Ext & Initial & Residue & \% Ext \\
\hline Total copper & 0.36 & 0.20 & 44.2 & 0.41 & 0.36 & 13.0 \\
Soluble copper & 0.04 & 0.02 & 50.0 & 0.04 & 0.02 & 50.0 \\
Cyanidable copper & 0.14 & 0.05 & 64.3 & 0.15 & 0.13 & 13.3 \\
Copper in residue & 0.18 & 0.14 & 22.2 & 0.22 & 0.21 & 4.5 \\
Total iron & 4.82 & 4.79 & & 4.87 & & 4.71 \\
\hline
\end{tabular}

3.2.5. Effect of Temperature and Sulfuric Acid/Sodium Chloride/Ferrous Sulfate Used during Agglomeration

By comparing the results obtained after leaching (see Table 11) when $\mathrm{H}_{2} \mathrm{SO}_{4}, \mathrm{NaCl}$, and $\mathrm{FeSO}_{4}$ added during agglomeration, in columns $5\left(32.9^{\circ} \mathrm{C}\right)$ and $9\left(14.5^{\circ} \mathrm{C}\right)$, it can be deduced that temperature is the predominant factor that improves dissolution of copper sulfides. These results are consistent for column leaching systems with those reported by Kimball et al. [31].

Table 11. Copper extractions in column $5\left(32.9^{\circ} \mathrm{C}, 0.6 \mathrm{~kg} \mathrm{H}_{2} \mathrm{SO}_{4} / 50 \mathrm{~kg}\right.$ of ore, $0.525 \mathrm{~kg} \mathrm{NaCl} / 50 \mathrm{~kg}$ of ore, $0.5 \mathrm{~kg} \mathrm{FeSO} 4 / 50 \mathrm{~kg}$ of ore) and column $9\left(14.5^{\circ} \mathrm{C}, 0.6 \mathrm{~kg} \mathrm{H}_{2} \mathrm{SO}_{4} / 50 \mathrm{~kg}\right.$ of ore, $0.525 \mathrm{~kg} \mathrm{NaCl} / 50 \mathrm{~kg}$ of ore, $0.5 \mathrm{~kg} \mathrm{FeSO} 4 / 50 \mathrm{~kg}$ of ore).

\begin{tabular}{ccccccc}
\hline & \multicolumn{3}{c}{ Column 5 } & \multicolumn{3}{c}{ Column 9 } \\
\hline & Initial & Residue & \% Ext & Initial & Residue & \% Ext \\
\hline Total copper & 0.47 & 0.23 & 51.9 & 0.45 & 0.40 & 12.4 \\
Soluble copper & 0.04 & 0.02 & 50.0 & 0.05 & 0.03 & 40.0 \\
Cyanidable copper & 0.19 & 0.04 & 78.9 & 0.17 & 0.16 & 5.9 \\
Copper in residue & 0.24 & 0.17 & 29.2 & 0.23 & 0.21 & 8.7 \\
Total iron & 4.97 & 4.91 & & 4.67 & 4.68 & \\
\hline
\end{tabular}

Column 5 shows $78.9 \%$ chalcocite-covellite, while column 9 shows only $5.9 \%$ extraction. Regarding the leaching of chalcopyrite (based on the copper present in the residue), column 5 shows an extraction of $29.2 \%$, while column 9 shows only $8.7 \%$.

\subsubsection{Effect of Ferrous Ion}

Similar copper extractions for the two columns agglomerated with $\mathrm{H}_{2} \mathrm{SO}_{4}, \mathrm{NaCl}$, and $\mathrm{FeSO}_{4}$, specifically column 5 (0.5 kg ferrous sulfate added; $51.9 \% \mathrm{Cu}$ extracted) compared with column 6 ( $1 \mathrm{~kg}$ ferrous sulfate added; $50.3 \% \mathrm{Cu}$ extracted), indicate that a greater amount of $\mathrm{FeSO}_{4}$ in the agglomeration stage does not improve leaching kinetics. Similarly, copper extractions for columns 2 and 3 indicate that $\mathrm{FeSO}_{4}$ alone has no notable effect on copper leaching, as there is little difference between them and column 1 (only agglomerated with acid).

Column 4 shows a greater extraction compared to columns 1, 2, and 3 as a consequence of $\mathrm{NaCl}$ addition during agglomeration (Figure 4). However, a comparison between columns 4, 5, and 6, indicates that the addition of $\mathrm{FeSO}_{4}$ results in higher extraction efficiency in the presence of $\mathrm{NaCl}$.

Columns operated at $14.5^{\circ} \mathrm{C}$ show less than $15 \%$ copper extractions, although they contain $\mathrm{NaCl}$ and $\mathrm{FeSO}_{4}$ added during agglomeration (Figure 4). This clearly indicates that the copper extraction in these tests is strongly temperature dependent. 


\subsubsection{Proposed Reactions in the Agglomeration-Curing Stage}

During the agglomeration-curing stage the following reactions may occur:

(a) Agglomeration only with the use of acid (columns 1 and 7): as the acid is not able to leach sulfide copper ore, ferric ion was supplied by the raffinate solution. The action of the ferric ion has been proposed by Nicol and Basson [38] and Dutrizac [7] as follows:

\begin{tabular}{lcc}
\hline Reactions & $\Delta \mathrm{G}^{0} \mathbf{1 4 . 5}{ }^{\circ} \mathrm{C}$ & $\Delta \mathrm{G}^{0} 32 .{ }^{\circ} \mathrm{C}$ \\
\hline $\mathrm{CuS}+2 \mathrm{Fe}^{3+}=\mathrm{Cu}^{2+}+2 \mathrm{Fe}^{2+}+\mathrm{S}$ & -5.936 & -6.858 \\
$\mathrm{Cu}_{2} \mathrm{~S}+4 \mathrm{Fe}^{3+}=2 \mathrm{Cu}^{2+}+4 \mathrm{Fe}^{2+}+\mathrm{S}$ & -18.411 & -20.136 \\
$\mathrm{CuFeS}_{2}+4 \mathrm{Fe}^{3+}=\mathrm{Cu}^{2+}+5 \mathrm{Fe}^{2+}+2 \mathrm{~S}$ & -30.819 & -32.671 \\
\hline
\end{tabular}

(b) Agglomeration with acid and chloride (columns 4 and 8): The addition of chloride enhances the leaching action of the ferric ion [41]. The following reactions could occur:

\begin{tabular}{lcc}
\hline Reactions & $\Delta \mathrm{G}^{0} \mathbf{1 4 . 5}{ }^{\circ} \mathrm{C}$ & $\Delta \mathrm{G}^{0} 32.9^{\circ} \mathrm{C}$ \\
\hline $\mathrm{CuS}+2 \mathrm{Fe}^{3+}+\mathrm{Cl}^{-}=\mathrm{CuCl}^{-}+2 \mathrm{Fe}^{2+}+\mathrm{S}$ & -6.438 & -7.416 \\
$\mathrm{Cu}_{2} \mathrm{~S}+4 \mathrm{Fe}^{3+}+2 \mathrm{Cl}^{-}=2 \mathrm{CuCl}^{-}+4 \mathrm{Fe}^{2+}+\mathrm{S}$ & -19.377 & -21.251 \\
$\mathrm{CuFeS}_{2}+4 \mathrm{Fe}^{3+}+\mathrm{Cl}^{-}=\mathrm{CuCl}^{-}+5 \mathrm{Fe}^{2+}+2 \mathrm{~S}$ & -31.321 & -33.229 \\
\hline
\end{tabular}

Agglomeration with acid, chloride, and ferrous (columns 5, 6, and 7): in this case, the addition of ferrous ions improves the total copper extractions compared to the leaching of agglomerates produced without the use of this reagent. Possibly its presence prevents or minimizes the formation of the passivation layer on the surface of the sulfides.

\section{Conclusions}

The effect of the modification of the agglomeration-curing stages and temperature on copper leaching kinetics of a copper sulfide ore was reached using $\mathrm{H}_{2} \mathrm{SO}_{4}, \mathrm{NaCl}$, and $\mathrm{FeSO}_{4}$.

In the column tests, the largest copper extractions were obtained when leaching was carried out at a temperature of $32.9^{\circ} \mathrm{C}$. As temperature increases, for the same agglomeration conditions, extraction is up to five times higher compared to leaching at $14.5^{\circ} \mathrm{C}$.

The highest copper extraction was obtained in column 5 ore agglomerated with $\mathrm{H}_{2} \mathrm{SO}_{4}, \mathrm{NaCl}$, and $1 \% w / w \mathrm{FeSO}_{4}$, in which an extraction of $50.23 \%$ of copper was achieved, followed by column 6 (agglomerated with $\mathrm{H}_{2} \mathrm{SO}_{4}, \mathrm{NaCl}$, and $2 \% w / w \mathrm{FeSO}_{4}$ ), where an extraction of $48.5 \%$ was obtained.

The next highest extraction, $41.84 \%$, was obtained in column 4 (agglomerated with $\mathrm{H}_{2} \mathrm{SO}_{4}$ and $\mathrm{NaCl}$ ). Copper extractions in the columns leached at $14.5{ }^{\circ} \mathrm{C}$ did not exceed $15 \%$, despite the addition of $\mathrm{NaCl}$ and $\mathrm{FeSO}_{4}$.

This medium, using ferrous-chloride, could be applied in the agglomerate stage, prior to heap leaching of copper sulfide minerals at an industrial scale.

Author Contributions: The authors contributions are the following: K.E.S. conceived, designed, and performed the experiments; O.H. and C.M.T. analyzed the data; K.E.S. also contributed with reagents $/$ materials/analysis tools; O.H., K.E.S. and C.M.T. wrote the paper.

Funding: Research office from Universidad Católica del Norte.

Acknowledgments: The authors are grateful to Laboratorio de Investigación de Procesos (LIP) from Universidad de Antofagasta for supporting the present study.

Conflicts of Interest: The authors declare no conflicts of interest. 


\section{References}

1. Ekman Nilsson, A.; Macias Aragonés, M.; Arroyo Torralvo, F.; Dunon, V.; Angel, H.; Komnitsas, K.; Willquist, K. A Review of the Carbon Footprint of $\mathrm{Cu}$ and $\mathrm{Zn}$ Production from Primary and Secondary Sources. Minerals 2017, 7, 168. [CrossRef]

2. Watling, H. Chalcopyrite hydrometallurgy at atmospheric pressure: 1 . Review of acidic sulfate, sulfate-chloride and sulfate-Nitrate process options. Hydrometallurgy 2013, 140, 163-180. [CrossRef]

3. Villarino, J. Reporte Anual del Consejo Minero 2011-2012; Consejo Minero: Santiago, Chile, 2012.

4. Munoz, P.; Miller, J.D.; Wadsworth, M.E. Reaction mechanism for the acid ferric sulfate leaching of chalcopyrite. Met. Trans. B 1979, 10, 149-158. [CrossRef]

5. Hiroyoshi, N.; Hirota, M.; Hirajima, T.; Tsunekawa, M. A case of ferrous sulfate addition enhancing chalcopyrite leaching. Hydrometallurgy 1997, 47, 37-45. [CrossRef]

6. Hiroyoshi, N.; Miki, H.; Hirajima, T.; Tsunekawa, M. Enhancement of chalcopyrite leaching by ferrous ions in acidic ferric sulfate solutions. Hydrometallurgy 2001, 60, 185-197. [CrossRef]

7. Dutrizac, J. The dissolution of chalcopyrite in ferric sulfate and ferric chloride media. Met. Trans. B 1981, 12, 371-378. [CrossRef]

8. Dutrizac, J. Elemental sulphur formation during the ferric chloride leaching of chalcopyrite. Hydrometallurgy 1990, 23, 153-176. [CrossRef]

9. Sokić, M.D.; Marković, B.; Živković, D. Kinetics of chalcopyrite leaching by sodium nitrate in sulphuric acid. Hydrometallurgy 2009, 95, 273-279. [CrossRef]

10. Senanayake, G. A review of chloride assisted copper sulfide leaching by oxygenated sulfuric acid and mechanistic considerations. Hydrometallurgy 2009, 98, 21-32. [CrossRef]

11. Flett, D. Chloride hydrometallurgy for complex sulphides: A review. CIM Bull. 2002, 95, 95-103.

12. Klauber, C. A critical review of the surface chemistry of acidic ferric sulphate dissolution of chalcopyrite with regards to hindered dissolution. Int. J. Miner. Process. 2008, 86, 1-17. [CrossRef]

13. Debernardi, G.; Carlesi, C. Chemical-electrochemical approaches to the study passivation of chalcopyrite. Miner. Process. Extr. Met. Rev. 2013, 34, 10-41. [CrossRef]

14. Stott, M.; Watling, H.; Franzmann, P.; Sutton, D. The role of iron-hydroxy precipitates in the passivation of chalcopyrite during bioleaching. Miner. Eng. 2000, 13, 1117-1127. [CrossRef]

15. Córdoba, E.; Muñoz, J.; Blázquez, M.; González, F.; Ballester, A. Leaching of chalcopyrite with ferric ion. Part II: Effect of redox potential. Hydrometallurgy 2008, 93, 88-96. [CrossRef]

16. Carneiro, M.F.C.; Leão, V.A. The role of sodium chloride on surface properties of chalcopyrite leached with ferric sulphate. Hydrometallurgy 2007, 87, 73-82. [CrossRef]

17. Vilcáez, J.; Inoue, C. Mathematical modeling of thermophilic bioleaching of chalcopyrite. Miner. Eng. 2009, 22, 951-960. [CrossRef]

18. Harmer, S.L.; Thomas, J.E.; Fornasiero, D.; Gerson, A.R. The evolution of surface layers formed during chalcopyrite leaching. Geochim. Cosmochim. Acta 2006, 70, 4392-4402. [CrossRef]

19. Ammou-Chokroum, M.; Cambazoglu, M.; Steinmez, D. Oxydation menagée de la chalcopyrite en solution acide: Analyses cinétique de réactions. II. Modéles diffusionales. Bull. Soc. Fr. Miner. Cristal. 1977, 100, 161-177.

20. Hiroyoshi, N.; Miki, H.; Hirajima, T.; Tsunekawa, M. A model for ferrous-promoted chalcopyrite leaching. Hydrometallurgy 2000, 57, 31-38. [CrossRef]

21. Kametani, H.; Aoki, A. Effect of suspension potential on the oxidation rate of copper concentrate in a sulfuric acid solution. Met. Trans. B 1985, 16, 695-705. [CrossRef]

22. Komnitsas, C.; Pooley, F. Optimization of the bacterial oxidation of an arsenical gold sulphide concentrate from Olympias, Greece. Miner. Eng. 1991, 4, 1297-1303. [CrossRef]

23. Al-Harahsheh, M.; Kingman, S.; Al-Harahsheh, A. Ferric chloride leaching of chalcopyrite: Synergetic effect of $\mathrm{CuCl}_{2}$. Hydrometallurgy 2008, 91, 89-97. [CrossRef]

24. Sato, H.; Nakazawa, H.; Kudo, Y. Effect of silver chloride on the bioleaching of chalcopyrite concentrate. Int. J. Miner. Process. 2000, 59, 17-24. [CrossRef]

25. Lu, Z.; Jeffrey, M.; Lawson, F. An electrochemical study of the effect of chloride ions on the dissolution of chalcopyrite in acidic solutions. Hydrometallurgy 2000, 56, 145-155. [CrossRef]

26. Li, J.; Kawashima, N.; Kaplun, K.; Absolon, V.J.; Gerson, A.R. Chalcopyrite leaching: The rate controlling factors. Geochim. Cosmochim. Acta 2010, 74, 2881-2893. [CrossRef] 
27. Kaplun, K.; Li, J.; Kawashima, N.; Gerson, A. Cu and Fe chalcopyrite leach activation energies and the effect of added $\mathrm{Fe}^{3+}$. Geochim. Cosmochim. Acta 2011, 75, 5865-5878. [CrossRef]

28. Viramontes-Gamboa, G.; Peña-Gomar, M.M.; Dixon, D.G. Electrochemical hysteresis and bistability in chalcopyrite passivation. Hydrometallurgy 2010, 105, 140-147. [CrossRef]

29. Sandström, Å.; Shchukarev, A.; Paul, J. XPS characterisation of chalcopyrite chemically and bio-leached at high and low redox potential. Miner. Eng. 2005, 18, 505-515. [CrossRef]

30. Hiroyoshi, N.; Kuroiwa, S.; Miki, H.; Tsunekawa, M.; Hirajima, T. Synergistic effect of cupric and ferrous ions on active-passive behavior in anodic dissolution of chalcopyrite in sulfuric acid solutions. Hydrometallurgy 2004, 74, 103-116. [CrossRef]

31. Kimball, B.E.; Rimstidt, J.D.; Brantley, S.L. Chalcopyrite dissolution rate laws. Appl. Geochem. 2010, 25, $972-983$. [CrossRef]

32. Lu, Z.; Jeffrey, M.; Lawson, F. The effect of chloride ions on the dissolution of chalcopyrite in acidic solutions. Hydrometallurgy 2000, 56, 189-202. [CrossRef]

33. Nicol, M.; Miki, H.; Velásquez-Yévenes, L. The dissolution of chalcopyrite in chloride solutions: Part 3. Mechanisms. Hydrometallurgy 2010, 103, 86-95. [CrossRef]

34. Yévenes, L.V.; Miki, H.; Nicol, M. The dissolution of chalcopyrite in chloride solutions: Part 2: Effect of various parameters on the rate. Hydrometallurgy 2010, 103, 80-85. [CrossRef]

35. Velásquez-Yévenes, L.; Nicol, M.; Miki, H. The dissolution of chalcopyrite in chloride solutions: Part 1. The effect of solution potential. Hydrometallurgy 2010, 103, 108-113. [CrossRef]

36. Nicol, M.J. The anodic behaviour of chalcopyrite in chloride solutions: Overall features and comparison with sulfate solutions. Hydrometallurgy 2017, 169, 321-329. [CrossRef]

37. Nicol, M.; Miki, H.; Zhang, S. The anodic behaviour of chalcopyrite in chloride solutions: Voltammetry. Hydrometallurgy 2017, 171, 198-205. [CrossRef]

38. Nicol, M.; Basson, P. The anodic behaviour of covellite in chloride solutions. Hydrometallurgy 2017, 172, 60-68. [CrossRef]

39. McBride, D.; Croft, T.; Cross, M.; Bennett, C.; Gebhardt, J. Optimization of a CFD-Heap leach model and sensitivity analysis of process operation. Miner. Eng. 2014, 63, 57-64. [CrossRef]

40. Ilankoon, I.; Neethling, S. Liquid spread mechanisms in packed beds and heaps. The separation of length and time scales due to particle porosity. Miner. Eng. 2016, 86, 130-139. [CrossRef]

41. Herreros, O. Lixiviación de Especies Sulfuradas de Cobre en Medios Clorurados: Aspectos Cinéticos y Termodinámicos; Editorial Académica Española: Beau Bassin, Mauritius, 2017. 